\section{Trace metal levels in the edible tissues of sea cucumbers (Holothuria tubulosa and Holothuria polii) from Sardinia (Western Mediterranean)}

\author{
Natalia Montero, ${ }^{1}$ Marco Atzori, ${ }^{1}$ \\ Barbara Marras, ${ }^{1}$ Alexandre Bettoschi, ${ }^{1}$ \\ Pierpaolo Nurchis, ${ }^{2}$ Valentina Coroneo, ${ }^{1}$ \\ Clara Sanna, ${ }^{1}$ Marco Schintu ${ }^{1}$ \\ ${ }^{1}$ Department of Medical Sciences and \\ Public Health, University of Cagliari; \\ ${ }^{2} \mathrm{SC}$ Health and Environment, \\ Prevention Department, ATS Sardegna, \\ Italy
}

\begin{abstract}
Sea cucumbers represent an important part of the diet in Asian and Pacific regions and are also used in traditional medicine. These habits have led to the overexploitation of local sea cucumber populations in these areas, driving the pursuit of new stock regions, such as Mediterranean areas. In Italy, contrarily to that observed for other Mediterranean countries, the exploitation of sea cucumber stocks is not extensive, which opens a new market opportunity. Thus, from a food safety perspective, this work aims at reporting the first assessment of trace metal concentrations (As, $\mathrm{Cd}, \mathrm{Cr}, \mathrm{Cu}, \mathrm{Hg}, \mathrm{Ni}, \mathrm{Pb}$ ) in the edible tissues of Holothuria polii and Holoturia tubulosa collected in Sardinia, the second-largest island in the Mediterranean Sea. Metal concentrations found in $H$. polii were generally higher than in H. tubulosa. However, in both species, they were lower than those reported for other areas of the Western Mediterranean. $\mathrm{Cd}, \mathrm{Hg}$, and $\mathrm{Pb}$ were below the limits established for seafood in Europe. As concentrations were in the range of those measured in other commercial seafood species in the Mediterranean. Thus, these species may be harvested and traded to fulfil the demands of local and international markets.
\end{abstract}

\section{Introduction}

The aim of a healthy lifestyle has triggered the search of new marine resources to be included in the diet and for medicinal purposes (e.g., Suleria et al. 2015). Sea cucumbers play an important role as a food and in traditional medicine in Asian and Pacific regions (catches of 20,000-40,000 tons/year) (Toral-Granda et al. 2008). Sea cucumber farming and fishing is not a common practice outside Southeast Asian and Pacific countries, but the overexploitation of local sea cucumber populations in these areas has driven the pursuit of new stock regions (Purcell et al. 2013; González-Wangüemert et al. 2018a). Thus, due to their commercial importance, currently, several Mediterranean countries (e.g., Turkey, Spain, Greece) are exploiting local sea cucumber resources for exporting (Conand 2017; González-Wangüemert et al. 2018a). In Italy, contrarily to that observed for other Mediterranean countries, the exploitation of sea cucumber stocks is not extensive, which opens a new market opportunity (Sicuro and Levine 2011). However, between 2015 and 2017, the illegal fishing of 53 tons of sea cucumbers was reported in Italy, specifically in Sardinia and the Puglia region (Meloni and Esposito 2018). The species displaying a greater commercial interest are Holothuria polii, $H$. tubulosa, H. mammata and Parastichopus regalis (González-Wangüemert et al. 2018a). Previous knowledge of these species refers mainly to nutritional and biometric studies (e.g., Aydin 2018), while few works have been published from a food safety perspective (e.g., Sicuro et al. 2012; González-Wangüemert et al. 2018b). Sea cucumbers belonging to the genus Holothuria, have been considered as useful biomonitors of environmental quality (Culha et al. 2016; Aydin et al. 2017). This is favored by their local-scale migratory movements, relatively long life-span and higher bioaccumulation capacity of pollutants than other organisms (Parra-Luna et al. 2020).

Seafood consumption is the major dietary source of exposure to arsenic (As), cadmium $(\mathrm{Cd})$, mercury $(\mathrm{Hg})$ and lead $(\mathrm{Pb})$, which have non-established biological functions and are considered non-essential metals (e.g., Domingo 2016). The potential danger of chemicals to the biota present in different ecosystems and human health has been recognized by the implementation of several national and international laws. Accordingly, in Europe, maximum levels for $\mathrm{Cd}, \mathrm{Hg}$ and $\mathrm{Pb}$ in seafood are set under Regulation No 1881/2006 (European Commission 2006) and posterior amendments. Regarding arsenic, Francesconi and Edmonds (1996) reported that its presence in seafood mainly consists of complex organic compounds that are generally non-toxic. However, the content of inorganic arsenic, a well-characterized carcinogen, should be considered in toxicity assessments (Luvonga et al. 2020).

Sardinia (Italy) is the second-largest island in the Mediterranean Sea. Information about the levels of trace metals in the tissues
Correspondence: Marco Schintu, Department of Medical Sciences and Public Health, University of Cagliari, Giovanni Porcell 4, 09124 Cagliari, Italy.

Tel.: +39.070.6758307.

E-mail: schintu@unica.it

Key words: Sea cucumber, Trace metals, Western Mediterranean, Seafood.

Acknowledgements: The authors are indebted with prof. Alessandra Padiglia, from Dipartimento di Scienze della Vita e dell'Ambiente, Università degli Studi di Cagliari, for the technical assistance in samples preparation.

Conflict of interest: The authors declare no conflict of interest.

Contributions: The authors contributed equally

Funding: None.

Availability of data and materials: All data and materials are available within the text.

Received for publication: 29 December 2020. Accepted for publication: 6 July 2021.

This work is licensed under a Creative Commons Attribution-NonCommercial 4.0 International License (CC BY-NC 4.0).

(C) Copyright: the Author(s), 2021

Licensee PAGEPress, Italy

Italian Journal of Food Safety 2021; 10:9576

doi:10.4081/ijfs.2021.9576

of autochthonous sea cucumber populations in this area of the Western Mediterranean is lacking. Thus, in the present study, $H$. tubulosa and $H$. polii sea cucumbers were collected in the Gulf of Cagliari (Sardinia) aiming to determine the levels of $\mathrm{As}, \mathrm{Cd}, \mathrm{Cr}$, $\mathrm{Cu}, \mathrm{Hg}, \mathrm{Ni}$, and $\mathrm{Pb}$ in their edible tissues, to compare them with the limits set by current seafood regulations. Moreover, comparing the obtained results with the most relevant sea cucumber data published in the Mediterranean in the last 20 years, this work provides an overall picture of trace metal concentrations in sea cucumbers in the Western Mediterranean area.

\section{Materials and methods}

\section{Study area}

Two areas, Giorgino and Foxi, were identified in the Gulf of Cagliari (Sardinia) as potential sites for the fishing of sea cucumbers based on the low levels of Escherichia coli in coastal waters (European 
Commission 2015; ARPAS 2017) (Figure 1). The Gulf of Cagliari is in the southern coast of Sardinia. It is bordered on the north by the urban area of Cagliari (about 400,000 inhabitants) and on the west by a heavily industrialized zone, which includes the largest oil refinery in the Mediterranean. Giorgino (39.165600 N-9.080100 E) on the west side of the gulf, is located in front of a loading and unloading terminal utilized by several medium and small size chemical companies. Foxi (39.217500 N-9.233167 E) is in the north side, in front of a touristic area only crowded in the summertime and not exposed to industrial pollutants or maritime traffic. Further information, regarding the environmental assessment of the Gulf of Cagliari, based on the heavy metal accumulation in sediments, and the geomorphological characteristics of the area can be found in Schintu et al. (2016) and Buosi et al. (2019), respectively.

\section{Sampling campaigns}

Sea cucumbers were collected in June and July 2017. Holothuria polii (Delle Chiaje 1823) was exclusively found in Foxi, while Holothuria tubulosa (Gmelin 1788) was only present in Giorgino. Nineteen specimens were fished in Foxi and fifteen in Giorgino, at a depth of 7-10 m. Sea cucumbers were collected by scuba divers and delivered to the laboratory in cooled sampling bags. Samples were stored in the freezer, at $-20^{\circ} \mathrm{C}$, until analysis. Physico-chemical parameters (Foxi: Temperature $24.4^{\circ} \mathrm{C}$, Salinity $35.8 \mathrm{ppt}, \mathrm{pH} 8.3$, Dissolved oxygen $>90 \%$; Giorgino: Temperature $24.8^{\circ} \mathrm{C}$, Salinity 35.7 ppt, $\mathrm{pH} 8.1$, Dissolved oxygen $>90 \%$ ) were measured in situ using a YSI multiprobe (Geoves, mod. MICROHYD1, B\&C electronics). The length of $H$. polii and H. tubulosa ranged from 9.1 to $13.0 \mathrm{~cm}(\mathrm{x}=11.4 \pm 1.2 \mathrm{~cm})$ and from 12.1 to $23.1 \mathrm{~cm}(\bar{x}=18.6 \pm 2.7 \mathrm{~cm})$, respectively; the weight ranged from 14.0 to $39.8 \mathrm{~g}(\overline{\mathrm{x}}=$ $26.6 \pm 5.7 \mathrm{~g}$ ) for $H$. polii specimens and from 31.9 to $58.0 \mathrm{~g}(\overline{\mathrm{x}}=48.4 \pm 6.5 \mathrm{~g})$ for H. tubulosa.

\section{Sample processing and analysis}

Following routine laboratory procedures when working with trace metals, all the material was soaked overnight in a $10 \%$ $\mathrm{HNO}_{3}$ acid bath and then rinsed with MilliQ (Zeener Power I Water Purification System, Human Corporation, South Korea) water before use.

The preparation of samples followed the procedure of Culha et al. (2016). Briefly, sea cucumbers were thawed, washed with tap and Milli-Q water and drained before dissection. The organisms were dissected longitudinally, from the anus to the mouth, and left to dry on absorbent paper. Visceral organs, gonads and pulmonary apparatus were completely removed. Edible muscle tissue was lyophilized using a LIO-5PDGT freeze-dryer (5Pascal, Italy) and consecutively reduced to powder. Following USEPA (1996), each sample (0.3 g) was transferred to $100-\mathrm{mL}$ Teflon digestion vessels, $7 \mathrm{~mL}$ of $\mathrm{HNO}_{3}$ (Suprapur $65 \%$, Merck Millipore, Germany) and $1 \mathrm{ml}$ of $\mathrm{H}_{2} \mathrm{O}_{2}$ (Suprapur 30\%, Merck Millipore,

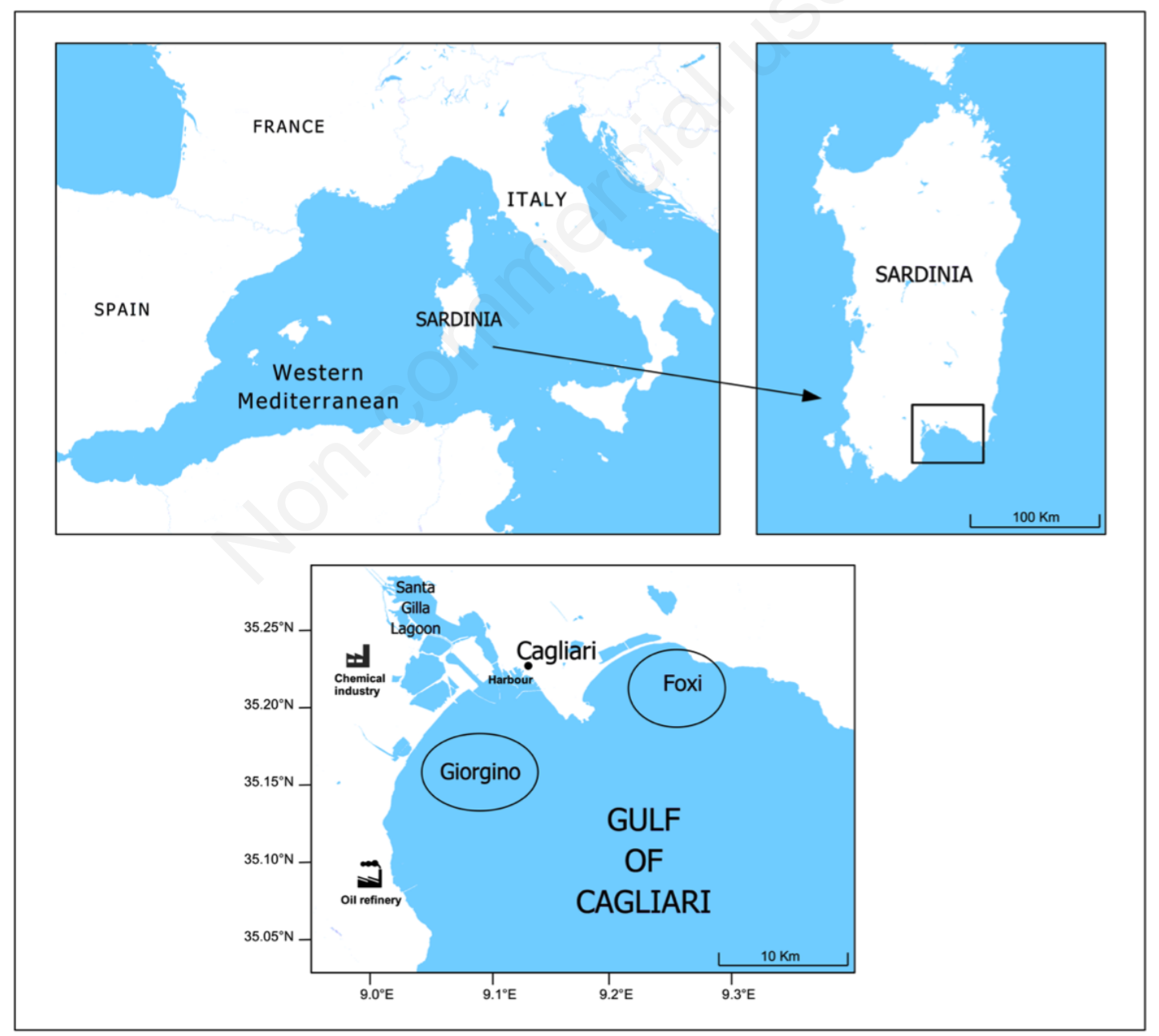

Figure 1. Sampling sites of Holothuria polii (Foxi) and Holothuria tubulosa (Giorgino) in the Gulf of Cagliari (Sardinia, Western Mediterranean). 
Germany) were added and samples were left to rest for 15-20 min. Samples were microwaved (see Schintu et al. 2016) and then, after cooling, samples were filtered through Whatman 41 filters (Whatman International Ltd., Maidstone, UK), made up to $50 \mathrm{~mL}$ with Milli-Q water and analyzed. Blanks were prepared following the same procedure, but without the addition of the samples.

Metal concentrations (As, $\mathrm{Cd}, \mathrm{Cr}, \mathrm{Cu}, \mathrm{Ni}$ and $\mathrm{Pb}$ ) were determined, following USEPA (1994), by graphite furnace atomic absorption spectroscopy (GFAAS Varian GTA120-AA240Z) using the Zeeman background correction. Total $\mathrm{Hg}$ was measured using a DMA-80 Direct Mercury Analyzer (Milestone, US). The quality control (QC) of the analysis was assured utilizing multi-element solutions that were prepared analogously to the calibration samples. The instrumental detection limits were as follows: $1 \mu \mathrm{g} \mathrm{L}^{-1}$ for As, $0.05 \mu \mathrm{g} \mathrm{L}^{-1}$ for $\mathrm{Cd}, 1 \mu \mathrm{g} \mathrm{L}^{-1}$ for $\mathrm{Cr}, 0.2 \mu \mathrm{g} \mathrm{L}^{-1}$ for $\mathrm{Cu}, 0.5$ $\mu \mathrm{g} \mathrm{L}{ }^{-1}$ for $\mathrm{Hg}, 1 \mu \mathrm{g} \mathrm{L} \mathrm{L}^{-1}$ for $\mathrm{Ni}$ and $0.5 \mu \mathrm{g} \mathrm{L}^{-1}$ for $\mathrm{Pb}$. The accuracy and precision (QA) of the analyses was checked by analyzing seven replicates of the certified reference material (CRM) IAEA-461 ('Trace elements and methylmercury mass fractions in clam Gafrarium tumidum sample'). The accuracies were within $10 \%$ of the certified values for all elements. Metal concentrations were expressed on a mg kg-1 dry weight basis.

\section{Statistical analysis}

Metal concentrations measured in the tissues of sea cucumbers are reported as the mean \pm standard error of the mean (SEM). Significant differences between species were determined by Student's t-test using the open-source Jamovi software (www.jamovi.org). Grubb's test was used for detecting outliers and corresponding values were not used for calculating the average concentration of metals. Shapiro-Wilk and Levene's tests were applied for the assessment of normality and homogeneity of variance, respectively. Significance level was set at $\alpha=0.05$.

\section{Results and discussion}

Results of metal concentrations measured in the edible tissues of sea cucumbers are presented in Figure 2. Considering that accumulation processes in these sea cucumber species might be different and that $H$. polii was only found in the sampling area Foxi and H. tubulosa in Giorgino, it is difficult to compare both species. However, in general, H. polii showed higher trace metal concentrations than H. tubulosa. The concentration of trace metals in $H$. polii decreased in the order $\mathrm{As}>\mathrm{Cu}>\mathrm{Pb}>\mathrm{Cr}>\mathrm{Ni}>\mathrm{Cd}>\mathrm{Hg}$, while in $H$. tubulosa the order was $\mathrm{As}>\mathrm{Cu}>\mathrm{Cr}>\mathrm{Pb}>\mathrm{Ni}>\mathrm{Hg}>\mathrm{Cd}$. Arsenic and $\mathrm{Cu}$ were the elements found in the highest concentrations in both species. Total As concentrations ranged from 18.3 to $30.5 \mathrm{mg}$ $\mathrm{kg}^{-1} \mathrm{dw}$ in $H$ polii, and from 13.2 to $24.8 \mathrm{mg}$ $\mathrm{kg}^{-1} \mathrm{dw}$ in H.tubulosa. Cu concentrations showed no statistically significant differences between the two species, while $H$ polii, collected in Foxi, presented significantly $\quad(p<0.001) \quad$ higher concentrations of $\mathrm{As}, \mathrm{Cd}, \mathrm{Cr}, \mathrm{Ni}$, and $\mathrm{Pb}$ than $H$. tubulosa from Giorgino. Contrarily, $H$. tubulosa presented significantly $(\mathrm{p}<0.001)$ higher $\mathrm{Hg}$ concentrations than H. polii. Since the fishing area of Foxi, in the north side of the Gulf, is less exposed to heavy metal pollution than the west side (ARPAS 2018), the higher metal concentrations present in sea cucumbers of this area is unexpected and requires further understanding of the processes taking place in that part of the gulf. On the other hand, the higher $\mathrm{Hg}$ concentrations in $H$. tubulosa can be explained by the exposition for decades to the legacy $\mathrm{Hg}$ pollution arising from a dismantled chlor-alkali plant located in the Santa Gilla Lagoon (Atzori et al. 2018; Figure 1). Among all studied metals, only As levels in the tissues of sea cucumbers were similar to those previously found in sediments of the Gulf of Cagliari (Schintu et al. 2016; 14-25 mg kg-1 dw). This might be explained by the use of sediments as food source and the lack of regulation of this metal (e.g., Storelli et al. 2001; Culha et al. 2016).

There is no previous information about trace metal concentrations in sea cucumbers in this part of the Mediterranean, thus, the levels found in the present study were compared with those measured in other areas of the Mediterranean (Table 1). In general, metal concentrations found in this study were lower. However, to assess the potential health risk of consuming these species, wet weight metal concentrations ( $\mathrm{mg} \mathrm{kg}^{-1} \mathrm{ww}$ ) were calculated, using the measured water content corresponding to H. tubulosa (81-

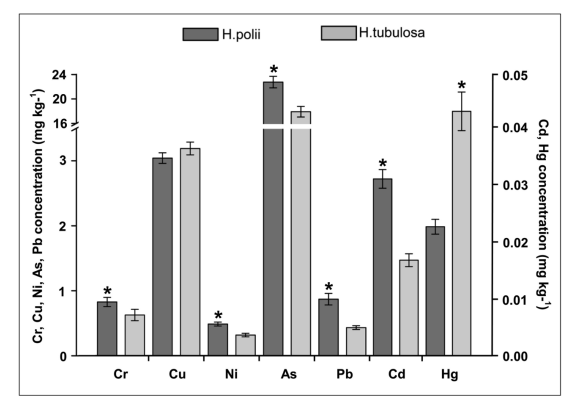

Figure 2. Trace metal concentrations (mg $\mathrm{kg}^{-1} \mathrm{dw}$ ) measured in the edible tissues of $H$. polii and $H$. tubulosa collected in the Gulf of Cagliari. Data are expressed as the mean \pm SEM. ${ }^{*}$ Denotes a statistically significant difference between species (Student's t-test, $\alpha=0.05$ ).

Table 1. Trace metal concentration $\left(\mathrm{mg} \mathrm{kg}^{-1} \mathrm{dw}\right)$ in the edible tissues of $H$. tubulosa (HT) and $H$. polii (HP) from other Mediterranean areas.

\begin{tabular}{|c|c|c|c|c|c|c|c|}
\hline Authors - Location & As & Cd & $\mathrm{Cr}$ & $\mathrm{Cu}$ & $\mathrm{Hg}$ & $\mathrm{Ni}$ & $\mathrm{Pb}$ \\
\hline Storelli et al. (2001) - Southern Adriatic Sea & - & 0.04 (HP) & - & 71 (HP) & $0.96(\mathrm{HP})$ & - & 1.3 (HP) \\
\hline $\begin{array}{l}\text { Warnau et al. (2006) - Calvi (Corse), } \\
\text { Ischia (Italy), Marseille (France) }\end{array}$ & - & $0.4-2.8(\mathrm{HT})$ & - & 0.8-5.8 (HT) & - & - & $1.2-18.0(\mathrm{HT})$ \\
\hline \multirow[t]{2}{*}{ Sicuro et al. (2012) - Southern Adriatic Sea } & 33.0 (HP) & 0.07 (HP) & 0.88 (HP) & $2.5(\mathrm{HP})$ & - & - & 0.65 (HP) \\
\hline & 22.0 (HT) & 0.07 (HT) & $0.86(\mathrm{HT})$ & $2.5(\mathrm{HT})$ & - & - & $1.2(\mathrm{HT})$ \\
\hline Culha et al. (2016) - Dardanelles Strait (Turkey) & - & $0.09-0.63(\mathrm{HT})$ & - & $0.02-6.6(\mathrm{HT})$ & - & 8.3-24.2 (HT) & $0.7-5.3(\mathrm{HT})$ \\
\hline Aydin et al. (2017) - Izmir coast (Turkey) & $1.3-13.3$ & $0.02-0.38$ & $0.05-4.3$ & $0.35-1.27$ & - & $0.01-0.65$ & $0.07-0.92$ \\
\hline González-Wangüemert et al. (2018b) - Murcia (Spain) & - & $\begin{array}{l}0.09(\mathrm{HP}) \\
\text { nd (HT) }\end{array}$ & $\begin{array}{l}0.77 \text { (HP) } \\
15.2(\mathrm{HT})\end{array}$ & $\begin{array}{l}- \\
-\end{array}$ & $\begin{array}{l}- \\
-\end{array}$ & $\begin{array}{l}\text { nd (HP) } \\
2.5(\mathrm{HT})\end{array}$ & $\begin{array}{l}3.1(\mathrm{HP}) \\
6.5(\mathrm{HT})\end{array}$ \\
\hline Current study - Sardinia (Italy) & $\begin{array}{l}22.9(\mathrm{HP}) \\
18.0(\mathrm{HT})\end{array}$ & $\begin{array}{l}0.03(\mathrm{HP}) \\
0.02(\mathrm{HT})\end{array}$ & $\begin{array}{l}0.84(\mathrm{HP}) \\
0.64(\mathrm{HT})\end{array}$ & $\begin{array}{l}3.1(\mathrm{HP}) \\
3.2(\mathrm{HT})\end{array}$ & $\begin{array}{l}0.023(\mathrm{HP}) \\
0.043(\mathrm{HT})\end{array}$ & $\begin{array}{l}0.50(\mathrm{HP}) \\
0.33(\mathrm{HT})\end{array}$ & $\begin{array}{l}0.88(\mathrm{HP}) \\
0.44(\mathrm{HT})\end{array}$ \\
\hline
\end{tabular}

nd, non-detected. 
Table 2. Mean ( $(\mathrm{SD})$ metal concentrations $\left(\mathrm{mg} \mathrm{kg}^{-1} \mathrm{ww}\right)$ measured in $H$. tubulosa and $H$. polii collected in the Gulf of Cagliari and maximum limit concentrations set by the European Commission (2006) seafood regulation.

\begin{tabular}{lccccccc} 
& As & $\mathrm{Cd}$ & $\mathrm{Cr}$ & $\mathrm{Cu}$ & $\mathrm{Hg}$ & $\mathrm{Ni}$ & $\mathrm{Pb}$ \\
H. tubulosa $\left(\mathrm{mg} \mathrm{kg}^{-1} \mathrm{ww}\right)$ & $2.2 \pm 0.5$ & $0.002 \pm 0.001$ & $0.07 \pm 0.03$ & $0.41 \pm 0.08$ & $0.005 \pm 0.002$ & $0.04 \pm 0.01$ & $0.05 \pm 0.01$ \\
H. polii $\left(\mathrm{mg} \mathrm{kg}^{-1} \mathrm{ww}\right)$ & $3.7 \pm 0.7$ & $0.005 \pm 0.001$ & $0.13 \pm 0.05$ & $0.50 \pm 0.11$ & $0.004 \pm 0.001$ & $0.08 \pm 0.02$ & $0.15 \pm 0.07$ \\
\hline EC $\left(\mathrm{mg} \mathrm{kg}{ }^{-1} \mathrm{ww}\right)$ & - & 1.0 & - & - & 0.5 & - & 1.5 \\
\hline
\end{tabular}

94\%) and $H$. polii (79-92\%) specimens, and compared with the maximum permissible limits set for human consumption (Table 2). The concentrations of $\mathrm{Cd}, \mathrm{Hg}$, and $\mathrm{Pb}$ were below the maximum levels set for seafood by the European Commission (2006) and posterior amendments. There are not guideline values for As in seafood in Europe, but total As concentrations found in tissues of $H$. polii $\left(3.7 \pm 0.7 \mathrm{mg} \mathrm{kg}^{-1} \mathrm{ww}\right)$ and $H$. tubulosa $\left(2.2 \pm 0.5 \mathrm{mg} \mathrm{kg}^{-1} \mathrm{ww}\right)$ were similar to those reported by Ferrante et al. (2019) in commonly consumed fresh seafood (mollusks $4.0 \pm 3.6 \mathrm{mg} \mathrm{kg}^{-1} \mathrm{ww}$; pelagic fish $6.5 \pm 7.2 \mathrm{mg} \mathrm{kg}^{-1} \mathrm{ww}$; demersal fish $5.1 \pm 5.4$ mg $\mathrm{kg}^{-1}$ ww), sampled along the Mediterranean coast. Thus, $H$. tubulosa and $H$. polii sea cucumbers found in the Gulf of Cagliari may be suitable for human consumption and their fishing for trading to Asian countries or their inclusion into the local marketplace could be pursued. In Sardinia, in 2015 and 2016, two areas were identified as potential sites for the fishing of sea cucumbers, following EC Regulation 2285/2015 (European Commission 2015). However, in February 2018 their harvesting in Italy was forbidden (IMAFFP 2018), following the precautionary principle, to counteract the effect of illegal fishing (Meloni and Esposito 2018). The banning was revoked at the end of 2019 , but the sustainable fishing of sea cucumbers will be only obtained combining severe laws, to combat illegal fishing, with the searching of new harvesting grounds, to reduce the pressure in single fishing areas. The results obtained in the present study open the possibility of including additional harvesting sites in the Western Mediterranean, based on a low level of contaminants, to limit the pressure over specific sea cucumber populations and ensure their long-term sustainable exploitation (e.g., Anderson et al. 2010).

\section{Conclusions}

The present study provides a first insight into the level of metals found in the edible tissues of sea cucumbers from Sardinia (Western Mediterranean). The results were compared with the data published in other areas of the Mediterranean in the last 20 years and evaluated for the limits set by food authorities. H. tubulosa and $H$. polii sea cucumbers found in the Gulf of Cagliari may be suitable for human consumption, based on the low metal concentrations present in tissues. This opens the possibility of including additional harvesting sites in the Western Mediterranean, contributing to the economic development of local fisheries.

\section{References}

Anderson SC, Flemming JM, Watson R, Lotze HK, 2010. Serial exploitation of global sea cucumber fisheries. Fish Fish 12:317-39.

ARPAS, 2017. Acque di balneazione della Sardegna: dati anno 2017. Agenzia Regionale per la Protezione dell'Ambiente della Sardegna, 143 pp. Available from: http://www.sardegnaambiente.it (accessed 15/12/2020)

ARPAS, 2018. Annuario dati ambientali della Sardegna. Sistema Nazionale per la Protezione dell'Ambiente, $111 \mathrm{pp}$.

Atzori G, Aru V, Marincola FC, Chiarantini L, Medas D, Sarais G, Cabiddu S, 2018. Sediments distribution of trace metals in a coastal lagoon (Southern Sardinia, Mediterranean Sea): assessment of contamination and ecological risk. Chem Ecol 34:727-46.

Aydin M, 2018. Biometry, density and the biomass of the commercial sea cucumber population of the Aegean Sea. Turk J Fish Aquat Sc 19:463-74.

Aydin M, Tunca E, Sahin UA, 2017. Effects of anthropological factors on the metal accumulation profiles of sea cucumbers in near industrial and residential coastlines of İzmir, Turkey. Int J Environ An Ch 97:368-82.

Buosi C, Ibba A, Passarella M, Porta M, Ruju A, Trogu D, De Muro S, 2019. Geomorphology, beach classification and seasonal morphodynamic transition of a Mediterranean gravel beach (Sardinia, Gulf of Cagliari). J Maps 15:165-76.
Conand C, 2017. Expansion of global sea cucumber fisheries buoys exports. Rev Biol Trop 65:S1-10.

Culha ST, Dereli H, Karaduman FR, Culha M, 2016. Assessment of trace metal contamination in the sea cucumber (Holothuria tubulosa) and sediments from the Dardanelles Strait (Turkey). Environ Sci Pollut Res 23:11584-97.

Domingo JL, 2016. Nutrients and chemical pollutants in fish and shellfish. Balancing health benefits and risks of regular fish consumption. Crit Rev Food Sci Nutr 56:979-88.

European Commission, 2006. Commission Regulation of 19 December 2006 setting maximum levels for certain contaminants in foodstuffs, 1881/2006/EC. In: Official Journal, L364/5, 19/12/2006.

European Commission, 2015. Commission Regulation of 8 December 2015 amending Annex II to Regulation (EC) No. 854/2004 of the European Parliament and of the Council laying down specific rules for the organization of official controls on products of animal origin intended for human consumption as regards certain requirements for live bivalve molluscs, echinoderms, tunicates and marine gastropods and Annex I to Regulation (EC) No. 2073/2005 on microbiological criteria for foodstuffs, 2285/2015/EU. In: Official Journal, L362/2, 08/12/2015.

Ferrante M, Napoli S, Grasso A, Zuccarello P, Cristaldi A, Copat C, 2019. Systematic review of arsenic in fresh seafood from the Mediterranean Sea and European Atlantic coasts: A health risk assessment. Food Chem Toxicol 126:322-31.

Francesconi KA, Edmonds JS, 1996. Arsenic and marine organisms. Adv Inorg Chem 44:147-89.

González-Wangüemert M, DomínguezGodino JA, Cánovas F, 2018a. The fast development of sea cucumber fisheries in the Mediterranean and NE Atlantic waters: from a new marine resource to its over-exploitation. Ocean Coast Manag 151:165-77.

González-Wangüemert M, Roggatz CC, Rodrigues MJ, Barreira L, Moreira da 
Silva M, Custódio L, 2018b. A new insight into the influence of habitat on the biochemical properties of three commercial sea cucumber species. Int Aquat Res 10:361-73.

IMAFFP, 2018. Italian Ministry of Agriculture of February 27th, 2018. Divieto della Pesca delle Oloturie, 156/2018/MD. In: Gazzetta Ufficiale della Repubblica Italiana, 88/2, 27/02/2018.

Luvonga C, Rimmer CA, Yu LL, Lee SB, 2020. Organoarsenicals in seafood: occurrence, dietary exposure, toxicity, and risk assessment considerations - A review. J Agric Food Chem 68:943-60.

Meloni D, Esposito G, 2018. Hygienic and commercial issues related to the illegal fishing and processing of sea cucumbers in the Mediterranean: a case study on over-exploitation in Italy between 2015 and 2017. Reg Stud Mar Sci 19:43-6.

Parra-Luna M, Martín-Pozo L, Hidalgo F, Zafra-Gómez A, 2020. Common sea urchin (Paracentrotus lividus) and sea cucumber of the genus Holothuria as bioindicators of pollution in the study of chemical contaminants in aquatic media. A revision. Ecol Indic 113:106185.
Purcell SW, Mercier A, Conand C, Hamel JF, Toral-Granda MV, Lovatelli A, Uthicke S, 2013. Sea cucumber fisheries: Global analysis of stocks, management measures and drivers of overfishing. Fish Fish 14:34-59.

Schintu M, Marrucci A, Marras B, Galgani F, Buosi C, Ibba A, Cherchi A, 2016. Heavy metal accumulation in surface sediments at the port of Cagliari (Sardinia, Western Mediterranean): Environmental assessment using sequential extractions and benthic foraminifera. Mar Pollut Bull 111:45-56.

Sicuro B, Levine J, 2011. Sea cucumber in the Mediterranean: a potential species for aquaculture in the Mediterranean. Rev Fish Sci 19:299-304.

Sicuro B, Piccino M, Gai F, Abete MC, Danieli A, Dapra F, Mioletti S, Vilella S, 2012. Food quality and safety of Mediterranean Sea cucumbers Holothuria tubulosa and Holothuria polii in Southern Adriatic Sea. Asian J Anim Vet Adv 7:851-9.

Storelli MM, Storelli A, Marcotrigiano GO, 2001. Heavy metals in the aquatic environment of the Southern Adriatic Sea, Italy - Macroalgae, sediments and benthic species. Environ Int 2687:505-9.

Suleria HAR, Osborne S, Masci P, Gobe G, 2015. Marine-based nutraceuticals: an innovative trend in the food and supplement industries. Mar Drugs 13:6336-51.

Toral-Granda V, Lovatelli A, Vasconcellos M, 2008. Sea cucumbers. A global review of fisheries and trade. FAO Fish Aquac Tech Paper 516, 317 pp.

USEPA, 1994. Method 200.9, Revision 2.2: Determination of trace elements by stabilized temperature graphic furnace atomic absorption. US Environmental Protection Agency, 43 pp.

USEPA, 1996. Method 3052, Microwave assisted acid digestion of siliceous and organically based matrices SW 846 Update III. US Environmental Protection Agency, 20 pp.

Warnau M, Dutrieux S, Ledent G, Rodríguez y Baena AM, Dúbois P, 2006. Heavy metals in the sea cucumber Holothuria tubulosa (Echinodermata) from the Mediterranean Posidonia oceanica ecosystem: body compartment, seasonal, geographical and bathymetric variations. Environ Bioind 1:268-85. 